\title{
Mineral Components in Aneurysms
}

\author{
Katarzyna Socha and Maria H. Borawska
}

Additional information is available at the end of the chapter

http://dx.doi.org/10.5772/47802

\section{Introduction}

Some studies reported imbalance of mineral components in patients with aneurysms [1-5]. The single available scientific reports from recent years describe the effect of certain dietary factors on the risk of aneurysm, such as eating high-cholesterol, fatty meat, alcohol consumption, inadequate intake of fruits and vegetables and also smoking. According to the authors of these papers it results in an increased incidence of aortic and cerebral aneurysms [6-9].

The objective of our research was investigation the relationships between content of selected mineral components: magnesium $(\mathrm{Mg})$, copper $(\mathrm{Cu})$, zinc $(\mathrm{Zn})$, selenium (Se), lead $(\mathrm{Pb})$ and cadmium $(\mathrm{Cd})$ and dietary habits and smoking in patients with abdominal aortic aneurysm (AAA) and cerebral aneurysm (CA). We compared the status of examined elements in patients with aneurysm and healthy people in similar age (control group).

\section{Material and methods}

We examined 4 groups:

1. Patients with AAA (45 men and 5 women) aged $42-81$ years, hospitalized at the Department of Vascular Surgery and Transplantology of Medical University of Bialystok, from which blood samples were taken. The samples of aortic wall and parietal thrombus were collected during surgery. The study included patients with an aneurysm diameter of $3.5-15 \mathrm{~cm}$. In $33 \%$ of patients occurred aneurysm rupture, in $37 \%$ was inflammatory aneurysm, and in $45 \%$ of patients femoral artery aneurysm coexisted;

2. Patients with CA (27 men and 43 women) aged 16 - 73 years, hospitalized at the Department of Neurosurgery of Medical University of Bialystok, from which blood samples were taken in the early phase (up to $72 \mathrm{hrs}$.) after the aneurysmal rupture; 
3. Healthy people $(n=22)$, appropriately matched to examined groups by age and gender, from which blood samples were taken - control group;

4. Aortic wall samples $(n=15)$ without aneurysm, taken from died people aged $39-79$ years - control group.

Food-frequency questionnaires were implemented to collect the dietary data. The patients with aneurysms were asked to complete the questionnaire concerning the consumption frequency of food product and smoking by the National Food and Nutrition Institute and the National Cardiology Institute [10]. 28 patients with CA, due to poor health were disclosed from nutritional information collecting. The list of food commodities consisted of 36 food items (white bread, wholegrain bread, sweets, cereal products, grain products, pulses, milk, cottage cheese, other sorts of cheese, meat, poultry, offal, sausages, ham, meat products, bacon, tinned meat, tinned fish, fresh fish, eggs, butter, margarine, vegetable oils, potatoes, processed vegetables, fresh vegetables, fruit, sugar added to beverages, marmalade, honey, soft drinks, beer, wine, vodka, coffee, tea). The consumption frequency of different kind of food was estimated according to the following criteria: frequent consumption was defined as an intake of certain food products twelve to thirty days per month, except fish, that was eaten four to twelve a month. Food products eaten less frequently were classified into "sporadic consumption" group.

The concentration of mineral components in deproteinated blood and tissues, after microwave mineralization in concentrated nitric acid, was analyzed by flame $(\mathrm{Mg}, \mathrm{Zn})$ and electrothermal $(\mathrm{Cu}, \mathrm{Se}, \mathrm{Pb}, \mathrm{Cd})$ atomic absorption spectrometry method with Zeeman-effect background correction on Z-5000 and Z-2000 instrument (Hitachi). Certified reference materials: Seronorm - human serum and whole blood, BCR184 - bovine muscle were used to test the accuracy of this methods. The results of the quality control analyses were in agreement with reference values. The Department of Bromatology participates in a quality control program of the estimation of trace elements of the National Institute of Public Health and Institute of Nuclear Chemistry and Technology.

Statistical analyses were performed using Statistica v. 9.1 software. Differences between independent groups were tested by the Mann-Whitney U-test. The correlations were calculated and tested by the Spearman rank test. For estimation the influence of dietary habits on content of mineral components in the examined patients we have used multiple linear regression analysis. Values of $\mathrm{p}<0.05$ were considered to be significantly different.

\section{Results and discussion}

\subsection{Magnesium (Mg)}

$\mathrm{Mg}$ as an activator of adenylate cyclase and ATPase cofactor is involved in most of the processes of the body. It participates in the synthesis and break-up of high-energy compounds, mainly ATP, activates enzymes involved in the metabolism of carbohydrates and fats, and is involved in protein synthesis [11]. Studies showed the efficacy of the compounds of $\mathrm{Mg}$ in the prevention and treatment of cardiovascular and nervous system, 
diabetes and some cancers, such as in the case of prostate cancer [12]. Mg decreases blood lipids, dilates blood vessels, reduces sensitivity to endogenous catecholamines, prevents hypercoagulability and reduces the sensitivity of the myocardium to hypoxia and also has anti-arrhythmic activity. In animal studies it was found that the deficiency of $\mathrm{Mg}$ causes hypercholesterolemia, hypertriglyceridemia and atherosclerosis [13]. $\mathrm{Mg}$ is one of the factors that modify the biosynthesis and degradation of elastin and collagen [14].

The average concentration of $\mathrm{Mg}$ in serum of patients with AAA was $21.88 \pm 2.52 \mathrm{mg} / \mathrm{L}$ and did not differ significantly from the contents of this element in serum of healthy people: $21.09 \pm 1.97 \mathrm{mg} / \mathrm{L}$. The average content of $\mathrm{Mg}$ in the aortic wall with aneurysm: $191.40 \pm$ $106.37 \mu \mathrm{g} / \mathrm{g}$ was significantly lower $(\mathrm{p}<0.03)$ compared to the concentration of this element in normal aorta - average: $299.15 \pm 234.98 \mu \mathrm{g} / \mathrm{g}$ (Table 1). The average content of $\mathrm{Mg}$ in the parietal thrombus was $47.63 \pm 11.93 \mu \mathrm{g} / \mathrm{g}$. There was no significant correlation between the content of $\mathrm{Mg}$ in examined tissues. We found that cigarette smoking decrease concentration of $\mathrm{Mg}$ in parietal thrombus of patients with AAA [15].

The average concentration of $\mathrm{Mg}$ in serum of patients with CA was $21.26 \pm 3.10 \mathrm{mg} / \mathrm{L}$ and did not differ significantly ( $p=0.368$ ) on the content of this element in the serum of healthy people: $20.62 \pm 2.06 \mathrm{mg} / \mathrm{L}$ - Table 1 [16].

\begin{tabular}{|c|c|c|c|}
\hline Type of aneurysm & $\begin{array}{r}\text { Concentr } \\
\text { (avera }\end{array}$ & $\begin{array}{l}\mathrm{n} \text { of } \mathrm{Mg} \\
\mathrm{SD})\end{array}$ & $\mathrm{p}$ \\
\hline \multirow{6}{*}{ AAA } & \multicolumn{2}{|c|}{ Serum $(m g / L)$} & \multirow{3}{*}{$\mathrm{p}_{1 / 2}=0.110$} \\
\hline & $\begin{array}{l}\text { 1. Control group } \\
(\mathrm{n}=22)\end{array}$ & $\begin{array}{l}\text { 2. Examined group } \\
\qquad(\mathrm{n}=49)\end{array}$ & \\
\hline & $21.09 \pm 1.97$ & $21.88 \pm 2.52$ & \\
\hline & \multicolumn{2}{|c|}{ Aortic wall $(\mu g / g)$} & \multirow{3}{*}{$\mathrm{p}_{3 / 4}<0.03$} \\
\hline & $\begin{array}{l}\text { 3. Without aneurysm } \\
\qquad(\mathrm{n}=14)\end{array}$ & $\begin{array}{l}\text { 4. With aneurysm } \\
\qquad(\mathrm{n}=49)\end{array}$ & \\
\hline & $299.15 \pm 234.98$ & $191.40 \pm 106.37 \downarrow$ & \\
\hline \multirow{3}{*}{ CA } & \multicolumn{2}{|c|}{ Serum $(m g / L)$} & \multirow{3}{*}{$p_{5 / 6}=0.368$} \\
\hline & $\begin{array}{l}\text { 5. Control group } \\
\qquad(\mathrm{n}=22)\end{array}$ & $\begin{array}{l}\text { 6. Examined group } \\
\qquad(\mathrm{n}=65)\end{array}$ & \\
\hline & $20.62 \pm 2.06$ & $21.26 \pm 3.10$ & \\
\hline
\end{tabular}

SD - standard deviation, $\mathrm{p}$ - significance level, $\mathrm{n}$ - number of samples

Table 1. Concentration of $\mathrm{Mg}$ in patients with abdominal aortic aneurysm (AAA), cerebral aneurysm (CA) and in the control groups.

One of the factors that eliminate the development of the aneurysm may be proper diet [6-9], including adequate supply of mineral components, which are essential factors in numerous metabolic processes functioning as coenzymes or biologically active substances. $\mathrm{Mg}$ is 
absorbed from diet in about $50 \%$, and there are many factors causing the negative balance of this element in the body. The source of $\mathrm{Mg}$ in the diet are: buckwheat, soya flour, cocoa, chocolate, seeds of legumes, spinach, wholegrain bread, nuts, figs, bananas, leafy vegetables, rice and fish [17].

Multiple regression analysis revealed a significant effect the dietary habits on $\mathrm{Mg}$ concentration in patients with the aneurysm. Dietary habits in about $50 \%\left(R^{2}=0.50\right)$ affected the concentration of $\mathrm{Mg}$ in the serum of the patients. Frequent consumption of fish and canned fish, grits, rice and legumes had the greatest influence on Mg status, but eating white bread, sweets and sugar was inversely correlated with concentration of $\mathrm{Mg}$. A similar correlation in the case of frequent consumption of sweet bakery products and sweets we found in previous studies assessing the concentration of $\mathrm{Mg}$ in patients with larynx cancer [18]. It is known that one reason for the negative balance of $\mathrm{Mg}$ in the system are diabetes and eating foods rich in sugar [17]. Analysis of the Spearman rank correlation showed that people often consumed white bread (which significantly decreased serum $\mathrm{Mg}$ levels) did not consume wholegrain bread $(\mathrm{r}=-.327, \mathrm{p}<0.05)$, which is a good source of $\mathrm{Mg}$.

\subsection{Copper $(\mathrm{Cu})$}

Imbalance in the concentrations of mineral elements in the human body is regarded as one of the risk factors for cardiovascular disease. The biological role of copper $(\mathrm{Cu})$ is related to its participation in the structures and functions of many enzymes (tyrosinase, cytochrome $\mathrm{c}$ oxidase, $\mathrm{Cu} / \mathrm{Zn}$ - superoxide dismutase, an antioxidant and anti-inflammatory). The role of $\mathrm{Cu}$ in the inflammation process has not been clearly defined. Significance for this process is its participation in the synthesis of prostaglandins in the arachidonic acid cascade. However, the greatest importance in influencing $\mathrm{Cu}$ in the inflammatory process has control of the synthesis of oxygen free radicals, resulting from the presence of this element in superoxide dismutase. In chronic inflammatory process associated with a severe phagocytosis generated free radical compounds that lead to tissue damage. Particularly susceptible to free radical attack are polyunsaturated fatty acids, which are then oxidized. This leads to damage of biological membranes and increase their permeability. $\mathrm{Cu}$ reducing the release of lysosomal enzymes by oxidation of membrane thiols to disulfides, to decrease the permeability of biological membranes. $\mathrm{Cu}$ also affects the inflammatory process by connecting to histamine, resulting in a decrease of its activity. This trace mineral plays an active role in the synthesis of collagen, elastin, myelin formation, affects bone formation and erythropoiesis [19]. The changes in the $\mathrm{Cu}$ content in the arterial wall are important because deficiency of this element may impair the formation of cross-links in collagen and elastin molecules, and thus cause a weakening of the elastic properties of elastin and collagen mechanical resistance and to increase the solubility of these proteins [20]. Cu promotion of angiogenesis is well documented. $\mathrm{Cu}$ stimulates endothelial cell proliferation and differentiation and promotes microtubule formation in cultured saphenous veins [21]. The enzyme lysyl oxidase (LOX) is a copper-dependent extracellular enzyme that catalyzes lysine-derived cross-links in collagen and elastin. LOX-mediated cross-linking of collagen 
types I and III fibrils leads to the formation of stiff collagen types I and III fibers and their subsequent tissue deposition. Evidence from experimental and clinical studies shows that the excess of LOX is associated with an increased collagen cross-linking and stiffness [22]. It has been suggested that ceruloplasmin, which binds more than $90 \% \mathrm{Cu}$ contained in human plasma and delivers $\mathrm{Cu}$ ions play an important role in the oxidative modification of low density lipoprotein (LDL). LDL contributes to the arising and development of atherosclerotic lesions in the arterial wall [23]. It was found that $\mathrm{Cu}$ is essential for the initiation of endothelial cell proliferation by the activation of angiogenic factors. Carcinogenic properties of $\mathrm{Cu}$ may also be related to its ability to bind to some proteins, giving them angiogenic activity [24].

The average concentration of $\mathrm{Cu}$ in serum of patients with AAA: $1.16 \pm 0.36 \mathrm{mg} / \mathrm{L}$ was significantly higher $(\mathrm{p}<0.03$ ) compared to the control group: $0.96 \pm 0.16 \mathrm{mg} / \mathrm{L}$ (Table 2$)$. The average content of $\mathrm{Cu}$ in the aneurysmal wall was $0.92 \pm 0.36 \mu \mathrm{g} / \mathrm{g}$, while in the parietal thrombus $1.50 \pm 0.92 \mu \mathrm{g} / \mathrm{g}$. We observed a significant correlation (correlation coefficient: $\mathrm{r}=$ $0.453, \mathrm{p}<0.012$ ) between the content of $\mathrm{Cu}$ in the aortic wall and parietal thrombus in patients with AAA [25].

Our new research showed that average content of $\mathrm{Cu}$ in serum of patients with $\mathrm{CA}$ was significantly $(\mathrm{p}<0.00003)$ lower $(0.777 \pm 0.32 \mathrm{mg} / \mathrm{L})$ than in the control group $(1.132 \pm 0.41$ $\mathrm{mg} / \mathrm{L}$ ) - Table 2. Imbalance in the concentration of $\mathrm{Cu}$ in the case of aneurysms have also been observed by other authors [1-2,4,5].

\begin{tabular}{|c|c|c|c|}
\hline Type of aneurysm & $\begin{array}{r}\text { Conce } \\
\text { (av }\end{array}$ & $\begin{array}{l}\text { on of } \mathrm{Cu} \\
\pm \mathrm{SD})\end{array}$ & $\mathrm{p}$ \\
\hline \multirow{3}{*}{ TAB } & \multicolumn{2}{|c|}{ Serum $(m g / L)$} & \multirow{3}{*}{$\mathrm{p}_{1 / 2}<0.03$} \\
\hline & $\begin{array}{l}\text { 1. Control group } \\
(\mathrm{n}=18)\end{array}$ & $\begin{array}{l}\text { 2. Examined group } \\
\qquad(\mathrm{n}=34)\end{array}$ & \\
\hline & $0.96 \pm 0.16$ & $1.16 \pm 0.36 \uparrow$ & \\
\hline \multirow[t]{2}{*}{ CA } & $\begin{array}{l}\text { 3. Control group } \\
(\mathrm{n}=22)\end{array}$ & $\begin{array}{l}\text { 4. Examined group } \\
\qquad(\mathrm{n}=78)\end{array}$ & \multirow[t]{2}{*}{$\mathrm{p}_{3 / 4}<0.00003$} \\
\hline & $1.132 \pm 0.41$ & $0.777 \pm 0.32 \downarrow$ & \\
\hline
\end{tabular}

SD - standard deviation, $\mathrm{p}$ - significance level, $\mathrm{n}$ - number of samples

Table 2. Concentration of $\mathrm{Cu}$ in patients with abdominal aortic aneurysm (AAA), cerebral aneurysm (CA) and in the control groups.

Dietary sources for $\mathrm{Cu}$ include whole grain cereals, legumes and green leafy vegetables, nuts, potatoes, oysters and other seafood, offal, poultry, cocoa, dried fruits such as prunes, raisins and yeast [26].

The increase of $\mathrm{Cu}$ concentration correlated positively with frequent consumption of ham, wholegrain products and negatively with frequent consumption of offal, probably due to higher concentrations of toxic elements in these products and their interactions [27]. 


\subsection{Zinc (Zn)}

The importance of zinc $(\mathrm{Zn})$ in the human body is associated with its multidirectional biological activity by taking part in over 300 enzymatic reactions and metabolic disorders. $\mathrm{Zn}$ is a stabilizer or a catalyst for more than 200 enzymes that are involved in the processes of cellular respiration, protein and carbohydrate metabolism [28]. The most important biological role of $\mathrm{Zn}$ is to participate in the metabolism of nucleic acids and protein synthesis as an essential component of RNA and DNA polymerases [29]. $\mathrm{Zn}$ is involved in the metabolism of fatty acids n-3 prostaglandins, which, depending on the type and concentration may act antiinflammatory, dilate blood vessels, lower blood pressure, prevent clotting, inhibit the synthesis of triglycerides and are essential in regulating the activity of $\mathrm{T}$ cells [30]. $\mathrm{Zn}$ is a protective factor in the structure and functioning of cell membranes, is involved in gene expression and cell differentiation. Due to the stabilizing properties of a protective effect on the integrity of the endothelial cell layer, which protects against harmful substances such as inflammatory cytokines and an excess of polyunsaturated fatty acids. It is suggest that an antiarteriosclerosis role of $\mathrm{Zn}$ is related to prevention of this particular factors [31,32]. $\mathrm{Zn}$ also participates in the synthesis of collagen [33]. Due to antioxidant activity and anti-inflammatory properties $\mathrm{Zn}$ possesses anticancer activity. It was found that $\mathrm{Zn}$ supplementation has a beneficial effect on the reduction of angiogenesis and induction of inflammatory cytokines while increasing apoptosis in tumor cells [34,35]. Zn decreases absorption of $\mathrm{Cu}$ by competing for binding to metallothionein [36].

The average concentration of $\mathrm{Zn}$ in the serum of patients with AAA $(0.653 \pm 0.271 \mathrm{mg} / \mathrm{L})$ was significantly lower $(\mathrm{p}<0.00007)$ than the level of $\mathrm{Zn}$ in serum in the control group: $0.996 \pm$ $0.260 \mathrm{mg} / \mathrm{L}$. The average content of $\mathrm{Zn}$ in the aortic wall with aneurysm was $21.157 \pm 12.582$ $\mu \mathrm{g} / \mathrm{g}$, whereas in normal aorta: $23.318 \pm 14.038 \mu \mathrm{g} / \mathrm{g}$ (Table 3). The average concentration of $\mathrm{Zn}$ in the parietal thrombus was $10.622 \pm 6.799 \mu \mathrm{g} / \mathrm{g}$ There was no significant correlation between the content of $\mathrm{Zn}$ in examined tissues [37].

The average concentration of $\mathrm{Zn}$ in the serum of patients with CA was significantly $(\mathrm{p}<0.03$ ) lower $(0.651 \pm 0.20 \mathrm{mg} / \mathrm{L})$ compared to the concentration of $\mathrm{Zn}$ in the serum of healthy subjects $(0.761 \pm 0.19 \mathrm{mg} / \mathrm{L})$ - Table 3 . We also showed that the level of $\mathrm{Zn}$ in the serum of patients who died during hospitalization was significantly $(\mathrm{p}<0.05)$ lower $(0.544 \pm 0.19 \mathrm{mg} /$ L) compared to the concentration of $\mathrm{Zn}$ in the serum of patients who survived $(0.684 \pm 020$ $\mathrm{mg} / \mathrm{L})$. There was a significantly $(\mathrm{p}<0.003)$ higher concentrations of $\mathrm{Zn}$ in serum of males $(0.875 \pm 0.17 \mathrm{mg} / \mathrm{L})$ compared to the level of serum $\mathrm{Zn}$ in females $(0.648 \pm 0.13 \mathrm{mg} / \mathrm{L})$ [38].

The absorption of $\mathrm{Zn}$ from food ranges from $10-40 \%$. The diet and age have influence on the bioavailability of Zn. Excess of calcium, copper, iron and selenium in the diet decreases the bioavailability. Phytic acid and dietary fiber, found in plant food decrease its absorption, but amino acids increase the bioavailability of $\mathrm{Zn}$. Food of animal origin (pork, poultry, fish, shellfish, oysters, offal, eggs, cheese) is one of the best sources of easily absorbed Zn. Plant products such as sunflower and pumpkin seeds, nuts, cereals with wholegrain bread, legume seeds, brown rice, onion, garlic and some mushrooms are also good sources of $\mathrm{Zn}$ $[32,39,40]$. 
Zn content significantly increased the frequent consumption of fish, canned fish and wholegrain breads, and decreased the frequent consumption of raw vegetables - probably due to the presence of these compounds impair the bioavailability $[37,38,40]$.

\begin{tabular}{|c|c|c|c|}
\hline Type of aneurysm & $\begin{array}{r}\text { Concent } \\
\text { (aver }\end{array}$ & $\begin{array}{l}n \text { of } \mathrm{Zn} \\
\mathrm{SD})\end{array}$ & $\mathrm{p}$ \\
\hline \multirow{6}{*}{ AAA } & \multicolumn{2}{|c|}{$\operatorname{Serum}(m g / L)$} & \multirow{3}{*}{$\mathrm{p}_{1 / 2}<0.00007$} \\
\hline & $\begin{array}{l}\text { 1. Control group } \\
(\mathrm{n}=16)\end{array}$ & $\begin{array}{l}\text { 2. Examined group } \\
\qquad(\mathrm{n}=42)\end{array}$ & \\
\hline & $0.996 \pm 0.260$ & $0.653 \pm 0.271 \downarrow$ & \\
\hline & \multicolumn{2}{|c|}{ Aortic wall $(\mu g / g)$} & \multirow{3}{*}{$\mathrm{p}_{3 / 4}=0.650$} \\
\hline & $\begin{array}{l}\text { 3. Without aneurysm } \\
\qquad(\mathrm{n}=9)\end{array}$ & $\begin{array}{l}\text { 4. With aneurysm } \\
\qquad(\mathrm{n}=42)\end{array}$ & \\
\hline & $23.318 \pm 14.038$ & $21.157 \pm 12.582$ & \\
\hline \multirow{3}{*}{ CA } & \multicolumn{2}{|c|}{ Serum $(m g / L)$} & \multirow{3}{*}{$\mathrm{p}_{5 / 6}<0.003$} \\
\hline & $\begin{array}{l}\text { 5. Control group } \\
(\mathrm{n}=22)\end{array}$ & $\begin{array}{l}\text { 6. Examined group } \\
\qquad(\mathrm{n}=57)\end{array}$ & \\
\hline & $0.761 \pm 0.19$ & $0.651 \pm 0.20 \downarrow$ & \\
\hline
\end{tabular}

SD - standard deviation, $\mathrm{p}$ - significance level, $\mathrm{n}$ - number of samples

Table 3. Concentration of $\mathrm{Zn}$ in patients with abdominal aortic aneurysm (AAA), cerebral aneurysm (CA) and in the control groups.

\subsection{Selenium (Se)}

Se is a micronutrient essential to maintain normal physiological functions, but also has an excess of adverse effects on the body. Se content in food, and consequently in the body, is dependent on its presence in the environment. Poland is one of the regions with low content of Se in soil and its overdose of food practically does not happen. More common is deficiency of this micronutrient [41,42]. So far, about 20 selenoprotein, including glutathione peroxidase, selenoproteins $\mathrm{P}$ and $\mathrm{W}$, iodothyronine deiodinase type 1,2 and 3, thioredoxin reductase, synthetase have been described [43]. Se is contained in the active center of glutathione peroxidase (GSH-Px) protecting the body against free radicals because of immunological and anti-inflammatory activities. Deficiency of Se can lead to cardiomyopathy and myocardial infarction, muscular dystrophy and fibrosis of pancreas [44]. Se is the element entered by selenocysteine into the genetic code and its low concentration may influence the increased risk of cancer (breast cancer, lung cancer) [4548]. The metabolism of Se in the brain is different than in other organs - deficiency of this element causes accumulation of increasing quantities of Se in brain. Although the function of many selenoproteins are not yet exactly known, an important role of Se in the functioning of the brain in its normal development and disease states, such as 
schizophrenia, Parkinson's or Alzheimer's disease is suggested [49]. Se also shows a detoxifying effect in the case of exposure to toxic elements such as lead and cadmium; these metal ions readily form stable connection in a complex of poorly soluble selenides excluding those elements from the biochemical processes and improving their elimination from the body [44].

The average Se level in serum of patients with AAA $(60.37 \pm 21.2 \mu \mathrm{g} / \mathrm{L})$ was significantly $(\mathrm{p}<$ $0.008)$ lower than in healthy volunteers $(75.87 \pm 22.4 \mu \mathrm{g} / \mathrm{L})$. The average serum Se concentration in the examined group was below the reference range, which is $70-140 \mu \mathrm{g} / \mathrm{L}$ [50]. We have not found differences between the content of Se in the aortic wall of patients with AAA ( $52.31 \pm 47.1 \mathrm{ng} / \mathrm{g}$ ) and the control group: $55.44 \pm 34.4 \mathrm{ng} / \mathrm{g}$ (died people) - Table 4 . The average concentration of $\mathrm{Se}$ in parietal thrombus was $139.82 \pm 44.6 \mathrm{ng} / \mathrm{g}$. We have observed a significant correlation $(r=0.69, \mathrm{p}<0.0001)$ between the content of Se in serum and the parietal thrombus of examined patients. We observed a significantly lower $(\mathrm{p}<0.05)$ concentration of Se in aortic wall of smoking than non-smoking patients [51].

The concentrations of Se in the serum of patients with CA $(73.248 \pm 13.30 \mu \mathrm{g} / \mathrm{L})$ were similar to the average content of Se in the control group $(75.789 \pm 22.07 \mu \mathrm{g} / \mathrm{L})$ - Table 4 [52].

\begin{tabular}{|c|c|c|c|}
\hline Type of aneurysm & $\begin{array}{r}\text { Concen } \\
\text { (aver } \\
\end{array}$ & $\begin{array}{l}\text { n of Se } \\
\text { SD) }\end{array}$ & $\mathrm{p}$ \\
\hline \multirow{6}{*}{ AAA } & \multicolumn{2}{|c|}{ Serum $(\mu g / L)$} & \multirow{3}{*}{$\mathrm{p}_{1 / 2}<0.008$} \\
\hline & $\begin{array}{l}\text { 1. Control group } \\
(n=22)\end{array}$ & $\begin{array}{l}\text { 2. Examined group } \\
\qquad(\mathrm{n}=49)\end{array}$ & \\
\hline & $75.87 \pm 22.4$ & $60.37 \pm 21.2 \downarrow$ & \\
\hline & \multicolumn{2}{|c|}{ Aortic wall (ng/g) } & \multirow{3}{*}{$\mathrm{p}_{3 / 4}=0.839$} \\
\hline & $\begin{array}{l}\text { 3. Without aneurysm } \\
\qquad(\mathrm{n}=17)\end{array}$ & $\begin{array}{l}\text { 4. With aneurysm } \\
\qquad(\mathrm{n}=40)\end{array}$ & \\
\hline & $55.44 \pm 34.4$ & $52.31 \pm 47.1$ & \\
\hline \multirow{3}{*}{ CA } & \multicolumn{2}{|c|}{$\operatorname{Serum}(\mu g / L)$} & \multirow{3}{*}{$\mathrm{p}_{5 / 6}=0.579$} \\
\hline & $\begin{array}{l}\text { 5. Control group } \\
(\mathrm{n}=22)\end{array}$ & $\begin{array}{l}\text { 6. Examined group } \\
\qquad(\mathrm{n}=38)\end{array}$ & \\
\hline & $75.79 \pm 22.1$ & $73.25 \pm 13.3$ & \\
\hline
\end{tabular}

SD - standard deviation, $\mathrm{p}$ - significance level, $\mathrm{n}$ - number of samples

Table 4. Concentration of Se in patients with abdominal aortic aneurysm (AAA), cerebral aneurysm (CA) and in the control groups.

The content of Se in the diet depends on its content in foods. High-protein products such as meat, meat offal, fish, eggs and poultry are good sources of Se. Additionally plant foods like nuts (especially Brazil), tomatoes, cucumbers, onions, garlic, broccoli, cabbage, wheat germ, wholegrain cereals are also good sources of Se [44]. 
The frequent consumption of raw vegetables significantly increased the concentration of Se, which is consistent with the literature because it is known that the plant food, in which Se is present as a selenomethionine and selenocysteine, characterized by a higher bioavailability compared to animal products $[44,53]$. In addition frequent consumption of wholegrain bread, grits, rice, meat products, ham, poultry, eggs and honey increased levels of Se in the patients. Eggs, especially egg yolk and poultry in our country are a significant source of Se due to the addition of Se compounds to feed. We estimated the content of Se in different meats and the highest content of Se was in the poultry [54]. The consumption of offal, canned meat, vodka and wine was inversely correlated with Se concentration in examined patients. It is known that alcohol impairs the absorption of minerals; sulfur compounds added to wine as preservatives shows competitive effect to selenium [55].

\subsection{Lead $(\mathrm{Pb})$}

$\mathrm{Pb}$ is toxic elements, taken from food and drinking water. $\mathrm{Pb}$ may accumulate in selected organs, such as blood, liver, kidney, brain and bone [56]. Toxic effects of $\mathrm{Pb}$ reveal in disorders of the circulatory system in the form of inhibition of synthesis of hemoglobin [57]. In addition to inhibition of enzymes involved in heme synthesis, $\mathrm{Pb}$ compounds may impair the functions of central and peripheral nervous system. With chronic exposure, there is also damage kidneys and liver [58]. Pb is considered as a potential immunotoxic factor. It exerts a direct toxic effect on cells of the immune system or modulate the immune response to antigens and mitogens, and also causes contact allergy and induces autoimmune disease [59].

There were no significant differences in the concentration of $\mathrm{Pb}$ in blood and aortic wall of patients with AAA $(27.96 \pm 20.3 \mu \mathrm{g} / \mathrm{L}, 162.65 \pm 157.2 \mathrm{ng} / \mathrm{g}$, respectively) compared to controls $(33.25 \pm 11.1 \mu \mathrm{g} / \mathrm{L}$ and $137.16 \pm 134.2 \mathrm{ng} / \mathrm{g}$, respectively) - Table 5 . The average concentration of $\mathrm{Pb}$ in the parietal thrombus was $7.979 .6 \mathrm{ng} / \mathrm{g}$. We found a significantly higher $(\mathrm{p}<0.05)$ concentration of $\mathrm{Pb}$ in aortic wall samples of smoking than non-smoking patients [51].

In patients with $\mathrm{CA}$ the blood $\mathrm{Pb}$ concentration $(48.98 \pm 37.4 \mu \mathrm{g} / \mathrm{L})$ was significantly higher $(\mathrm{p}<0.028)$ compared to healthy people $(29.63 \pm 22.8 \mu \mathrm{g} / \mathrm{L})$ - Table 5 [60].

Approximately $80 \%$ of $\mathrm{Pb}$ absorbs to the body through food. The source of $\mathrm{Pb}$ in the diet is mostly plant food: leafy and root vegetables, potatoes, cereals, legumes, cucurbits and tomatoes. Offal, meat and fish also may be contaminated with $\mathrm{Pb}$ compounds and processes, and packaging add to the contents of $\mathrm{Pb}$ in food [56].

The concentration of $\mathrm{Pb}$ can increase the frequent consumption of wholegrain products, and cooked vegetables, but consumption of grits, rice and honey may have positively influence on $\mathrm{Pb}$ status $[51,60]$.

\subsection{Cadmium (Cd)}

$\mathrm{Cd}$, like $\mathrm{Pb}$, is also a toxic element. Interaction of $\mathrm{Cd}$ with elements such as $\mathrm{Zn}, \mathrm{Cu}, \mathrm{Fe}$, $\mathrm{Mg}, \mathrm{Ca}, \mathrm{Se}$, which are essential for the body, causes morphological and functional changes 
in specific organs. Cd impairs carbohydrate metabolism, insulin secretion, inhibits the activity of oxidases and induces lipid peroxidation. Chronic exposure to $\mathrm{Cd}$ deteriorates kidney function, demineralization of bone, nervous system disorders, immune, and hyperglycemia [59,61,62]. Prolonged exposure to $\mathrm{Cd}$ can cause cardiovascular diseases. It is known that $\mathrm{Cd}$ can affect the formation of hypertension, which is probably caused by insufficient oxygen renin release from the kidney, which accumulate large amounts of metallothionein [63].

\begin{tabular}{|c|c|c|c|}
\hline Type of aneurysm & $\begin{array}{r}\text { Concen } \\
\text { (aver }\end{array}$ & $\begin{array}{l}\text { n of } \mathrm{Pb} \\
\pm \mathrm{SD})\end{array}$ & $\mathrm{p}$ \\
\hline \multirow{6}{*}{ AAA } & \multicolumn{2}{|c|}{ Blood $(\mu g / L)$} & \multirow{3}{*}{$\mathrm{p}_{1 / 2}=0.327$} \\
\hline & $\begin{array}{l}\text { 1. Control group } \\
\qquad(\mathrm{n}=22)\end{array}$ & $\begin{array}{l}\text { 2. Examined group } \\
\qquad(\mathrm{n}=49)\end{array}$ & \\
\hline & $33.25 \pm 11.1$ & $27.96 \pm 20.3$ & \\
\hline & \multicolumn{2}{|c|}{ Aortic wall (ng/g) } & \multirow{3}{*}{$\mathrm{p}_{3 / 4}=0.562$} \\
\hline & $\begin{array}{l}\text { 3. Without aneurysm } \\
\qquad(\mathrm{n}=17)\end{array}$ & $\begin{array}{l}\text { 4. With aneurysm } \\
\qquad(\mathrm{n}=40)\end{array}$ & \\
\hline & $137.16 \pm 134.2$ & $162.65 \pm 157.2$ & \\
\hline \multirow{3}{*}{ CA } & \multicolumn{2}{|c|}{ Blood $(\mu g / L)$} & \multirow{3}{*}{$\mathrm{p}_{5 / 6}<0.03$} \\
\hline & $\begin{array}{l}\text { 5. Control group } \\
(\mathrm{n}=22)\end{array}$ & $\begin{array}{l}\text { 6. Examined group } \\
\qquad(\mathrm{n}=64)\end{array}$ & \\
\hline & $29.63 \pm 22.75$ & $48.98 \pm 37.36 \uparrow$ & \\
\hline
\end{tabular}

SD - standard deviation, $\mathrm{p}$ - significance level, $\mathrm{n}$ - number of samples

Table 5. Concentration of $\mathrm{Pb}$ in patients with abdominal aortic aneurysm (AAA), cerebral aneurysm (CA) and in the control groups.

The average blood Cd concentrations in AAA and CA patients were similar to the control groups. There was also no significant differences in content of $\mathrm{Cd}$ between aortic wall with aneurysm and normal aorta - Table $6[60,64]$. Cigarette smoking did not influence on content of $\mathrm{Cd}$ in examined patients.

Food is one of the sources of exposure to $\mathrm{Cd}$, in addition to environmental and occupational exposure. High content of Cd may contain offal, fish and seafood and vegetable products from the areas contaminated with this element, such as leafy and root vegetables and mushrooms [56].

The frequent consumption of boiled and raw vegetables, and meat products contributed to the increase concentration of $\mathrm{Cd}$, while frequent consumption of grits and rice decreased its level in the patients with aneurysms. Various species of grits and rice, especially brown rice, due to its high content of essential minerals can protect against the accumulation of toxic elements in the body $[60,64]$. 


\begin{tabular}{|c|c|c|c|}
\hline Type of aneurysm & $\begin{array}{r}\text { Concent } \\
\text { (aver }\end{array}$ & $\begin{array}{l}\mathrm{n} \text { of } \mathrm{Cd} \\
\mathrm{SD})\end{array}$ & $\mathrm{p}$ \\
\hline \multirow{6}{*}{ AAA } & \multicolumn{2}{|c|}{ Blood $(\mu g / L)$} & \multirow{3}{*}{$\mathrm{p}_{1 / 2}=0.748$} \\
\hline & $\begin{array}{l}\text { 1. Control group } \\
\qquad(\mathrm{n}=20)\end{array}$ & $\begin{array}{l}\text { 2. Examined group } \\
\qquad(\mathrm{n}=42)\end{array}$ & \\
\hline & $2.60 \pm 2.42$ & $3.22 \pm 2.27$ & \\
\hline & \multicolumn{2}{|c|}{ Aortic wall (ng/g) } & \multirow{3}{*}{$\mathrm{p}_{3 / 4}=0.824$} \\
\hline & $\begin{array}{l}\text { 3. Without aneurysm } \\
\qquad(n=6)\end{array}$ & $\begin{array}{l}\text { 4. With aneurysm } \\
\qquad(\mathrm{n}=42)\end{array}$ & \\
\hline & $75.47 \pm 27.27$ & $72.32 \pm 32.69$ & \\
\hline \multirow{3}{*}{ CA } & \multicolumn{2}{|c|}{ Blood $(\mu g / L)$} & \multirow{3}{*}{$\mathrm{p}_{5 / 6}=0.342$} \\
\hline & $\begin{array}{l}\text { 5. Control group } \\
(\mathrm{n}=22)\end{array}$ & $\begin{array}{l}\text { 6. Examined group } \\
\qquad(\mathrm{n}=64)\end{array}$ & \\
\hline & $1.652 \pm 1.70$ & $1.252 \pm 1.14$ & \\
\hline
\end{tabular}

$\mathrm{SD}$ - standard deviation, $\mathrm{p}$ - significance level, $\mathrm{n}$ - number of samples

Table 6. Concentration of $\mathrm{Cd}$ in patients with abdominal aortic aneurysm (AAA), cerebral aneurysm (CA) and in the control groups.

\section{Conclusions}

Serum $\mathrm{Zn}$ concentration in patients with AAA and CA is significantly decreased. In turn, serum concentration of $\mathrm{Cu}$ in patients with AAA is increased, but decreased in the case of CA. On the other hand, serum concentration of Se in patients with AAA is lower when compared to healthy people, but does not change in the CA. The content of $\mathrm{Mg}$ is decreased only in the aortic wall with aneurysm, but its concentration in serum does not change in both types of aneurysms. The concentration of $\mathrm{Pb}$ is only increased in the blood of people with CA, while the concentration of $\mathrm{Cd}$ in the blood is comparable to healthy people in both types of aneurysms.

Dietary habits (frequency of consumption of each group of food products) may affect directly or indirectly on the content of the $\mathrm{Mg}, \mathrm{Cu}, \mathrm{Zn}, \mathrm{Se}, \mathrm{Pb}$ and $\mathrm{Cd}$ in people with AAA and CA.

Our results may help to explain the role of mineral components in case of aneurysms and be important in the prevention of this diseases.

\section{Author details}

Katarzyna Socha* and Maria H. Borawska

Department of Bromatology, Medical University of Bialystok, Poland

${ }^{*}$ Corresponding Author 


\section{Acknowledgement}

We wish to thank our colleagues: Prof. Marek Gacko, Dr Andrzej Guzowski from Department of Vascular Surgery and Transplantology, Medical University of Bialystok and Prof. Zenon Mariak, Dr hab. Jan Kochanowicz from Department of Neurosurgery, Medical University of Bialystok; for cooperation and clinical consultations.

\section{References}

[1] de Figueiredo Borges L, Martelli H, Fabre M, Touat Z, Jondeau G, Michel JB (2010) Histopathology of an Iliac Aneurysm in a Case of Menkes Disease. Pediatr. dev. pathol. 13 (3): 247-251.

[2] Gacko M, Głowiński S, Worowska A (1999) Zawartość Cynku, Magnezu, Manganu, Miedzi i Żelaza w Ścianie Tętniaka Aorty (in Polish). Biul. magnezol. 4 (2): 322-324.

[3] Iskra M, Majewski W, Piorunska-Stolzmann M (2002) Modifications of Magnesium and Copper Concentrations in Serum and Arterial Wall of Patients with Vascular Diseases Related to Ageing, Atherosclerosis and Aortic Aneurysm. Magnes. res. 15 (3-4): 279-285.

[4] Iskra M, Patelski J, Majewski W (1997) Relationship of Calcium, Magnesium, Zinc and Copper Concentrations in the Arterial Wall and Serum in Atherosclerosis Obliterans and Aneurysm. J. trace elem. med. biol. 11 (4): 248-252.

[5] Koksal C, Ercan M, Bozkurt AK, Cortelekoglu T, Konukoglu D (2007) Abdominal Aortic Aneurysm or Aortic Occlusive Disease: Role of Trace Element Imbalance. Angiology 58 (2): 191-195.

[6] Gopal K, Kumar K, Nandini R, Jahan P, Kumar MJ (2010) High Fat Diet Containing Cholesterol Induce Aortic Aneurysm Through Recruitment and Proliferation of Circulating Agranulocytes in apoE Knock Out Mice Model. J. thromb. thrombolysis . 30 (2): 154-163.

[7] Kent KC, Zwolak RM, Egorova NN, Riles TS, Manganaro A, Moskowitz AJ, Gelijns AC, Greco G (2010) Analysis of Risk Factors for Abdominal Aortic Aneurysm in a Cohort of More Than 3 Million Individuals. J. vasc. surg. 52 (3): 539-548.

[8] Shiue I, Arima H, Hankey GJ, Anderson CS (2011) Dietary Intake of Key Nutrients and Subarachnoid Hemorrhage: a Population-based Case-control Study in Australasia. Cerebrovasc. dis. 31(5): 464-470.

[9] Wong DR, Willett WC, Rimm EB (2007) Smoking, Hypertension, Alcohol Consumption, and Risk of Abdominal Aortic Aneurysm in Men. Am. j. epidemiol. 165 (7): 838-845.

[10] Sygnowska E, Waśkiewicz A, Pardo B (1997) Zmiany Zwyczajowego Sposobu Żywienia Populacji Warszawy Objętej Programem Pol-MONICA w latach 1984-93 (in Polish). Żyw. człow. metab. 24: 234-248.

[11] Classen HG, Grimm P (1992) Pharmacokinetics of Magnesium Salts. Methods find. exp. clin. 14 (4): 261-268.

[12] Dai Q, Motley SS, Smith JA Jr, Concepcion R, Barocas D, Byerly S, Fowke JH (2011) Blood Magnesium, and the Interaction with Calcium, on the Risk of High-grade Prostate Cancer. PLoS One 6(4): e18237. 
[13] Altura BT, Brust M, Bloom S, Barmour RL, Stempak JG, Altura BM (1990) Magnesium Dietary Intake Modulates Blood Lipid Levels and Artherogenesis. Proc. natl. acad sci. USA 87: 1840-1844.

[14] Gacko M (2000) Eksperymentalny Tętniak Aorty (in Polish). Post. hig. med. dośw. 54 (5): 699-722.

[15] Socha K, Borawska M, Gacko M, Guzowski A, Markiewicz R (2006) Dieta a Zawartość Magnezu w Surowicy, Ścianie i Skrzeplinie Przyściennej Tętniaka Aorty Brzusznej (in Polish). Bromat. chem. toksykol. 39: 655-658.

[16] Socha K, Borawska MH, Mariak Z, Kochanowicz J, Soroczyńska J (2009) Dieta a Zawartość Magnezu w Surowicy Pacjentów z Tętniakiem Mózgu (in Polish). Bromat. chem. toksykol. 42: 666-671.

[17] Ziemlański Ś (2001) Normy Żywienia Człowieka. Fizjologiczne Podstawy (in Polish). Warsaw: PZWL. pp. 349-362.

[18] Borawska MH, Czyżewska E, Łazarczyk B, Socha K (2005) Wpływ Nawyków Żywieniowych na Zawartość Magnezu u Ludzi z Nowotworami Krtani (in Polish). Bromat. chem. toksykol. 38: 639-642.

[19] Sobol G, Pyda E, Darmolińska B, Mizia A (2000) Biologiczna Rola Cynku i Miedzi i Ich Znaczenie dla Przebiegu Procesu Zapalnego (in Polish). Przeg. pediat. 30 (1): 7-9.

[20] Grant ME, Steven FS, Jakson DS (1971) Carbohydrate Content of Insoluble Elastins Prepared from Adult Bovine and Calf Ligamentum Nuchae and Tropoelastin Isolated from Copper-deficient Porcine Aorta. Biochem j. 121: 197-202.

[21] Kang YJ (2011) Copper and Homocysteine in Cardiovascular Diseases. Pharmacol. ther. 129(3): 321-31.

[22] López B, González A, Hermida N, Valencia F, de Teresa E, Díez J (2010) Role of Lysyl Oxidase in Myocardial Fibrosis: from Basic Science to Clinical Aspects. Am. j. physiol. heart circ. physiol. 299 (1): H1-9.

[23] Lamb DJ, Leake DS (1994) Acidic $\mathrm{pH}$ Enables Ceruloplasmin to Catalyse the Modification of Low Density Lipoprotein. FEBS lett. 338: 122-126.

[24] Nasulewicz A, Opolski A (2002) Rola Miedzi w Procesie Angiogenezy NowotworowejImplikacje Kliniczne (in Polish) Post. hig. med. dośw. 6: 691-705.

[25] Hukałowicz K, Borawska M, Gacko M, Guzowski A, Czyżewska E (2004) The Contents of Copper in Serum, Arterial Wall and Parietal Thrombus of Patients with Aortic Abdominal Aneurysm. Metal ions biol. med., 8: 456-459.

[26] Trumbo P, Yates AA, Schlicker S, Poos M (2001) Dietary Reference Intakes: Vitamin A, Vitamin K, Arsenic, Boron, Chromium, Copper, Iodine, Iron, Manganese, Molybdenum, Nickel, Silicon, Vanadium, and Zinc. J. am. diet. assoc. 101 (3): 294-301.

[27] Markiewicz R, Borawska MH, Socha K, Roszkowska M (2006) Content of Selenium and Lead in Some Tissues of Animals from Podlasie as an Indicator of Environmental Conditions. Pol. j. environ. stud. 15 (2a): 135-138.

[28] Nogowska M, Jelińska A, Muszalska I, Stanisz B (2000) Funkcje Biologiczne Makro- i Mikroelementów (in Polish). Farm. pol. 56 (21): 995-1004.

[29] Prasad AS (1983) Zinc Deficiency in Human Subjects. Prog. clin. biol. res. 129: 1-33. 
[30] Bao B, Prasad AS, Beck FW. Fitzgerald JT, Snell D, Bao GW, Singh T, Cardozo LJ (2010) Zinc Decreases C-reactive Protein, Lipid Peroxidation, and Inflammatory Cytokines in Elderly Subjects: a Potential Implication of Zinc as an Atheroprotective Agent. Am. j. clin. nutr. 91 (6): 1634-1641.

[31] Kuliczkowski W, Jołda-Mydłowska B, Kobusiak-Prokopowicz M, AntonowiczJuchniewicz J, Kosmala W (2004) Wpływ Jonów Wybranych Metali Ciężkich na Czynność Śródbłonka u Pacjentów z Chorobą Niedokrwienną Serca (in Polish). Pol. arch. med. wewn. 111 (6): 682-683.

[32] Puzanowska-Tarasiewicz H, Kuźmicka L, Tarasiewicz M (2009) Funkcje Biologiczne Wybranych Pierwiastków. III. Cynk - Składnik i Aktywator enzymów (in Polish). Pol. merk. lek. 161 (27): 419-421.

[33] Panek B, Gacko M, Pałka J (2004) Metalloproteinases, Insulin-like Growth Factor-I and its Binding Proteins in Aortic Aneurysm. Int. j. exp. pathol. 85 (3): 159-164.

[34] Prasad AS, Beck FW, Doerr TD, Shamsa FH, Penny HS, Marks SC, Kaplan J, Kucuk O, Mathog RH (1998) Nutritional and Zinc Status of Head and Neck Cancer Patients: an Interpretive Review. J. am. coll. nutr. 17 (5): 409-418.

[35] Prasad AS, Beck FW, Snell DC, Kucuk O (2009) Zinc in Cancer Prevention. Nutr. cancer.61 (6): 879-887.

[36] Milne D, Canfield W. Mahalko J (1984) Effect of Oral Folic Acid Supplements on Zinc, Copper and Iron Absorption and Excretion. Am. j. clin. nutr. 39: 535-539.

[37] Socha K, Borawska M, Gacko M, Guzowski A, Markiewicz R (2005) Dieta a Zawartość Cynku w Surowicy Krwi, Subkomórkowej Ścianie i Skrzeplinie Przyściennej Tętniaka Aorty (in Polish). Żyw. człow. metab. 32: 380-384.

[38] Socha K, Borawska MH, Mariak Z, Kochanowicz J, Markiewicz R (2009) Diet and Content of Zinc in Serum of Patients with Brain Aneurysm. Fresenius environ. bull. 18, 10a: 1932-1936.

[39] Koźlicka I, Przysławski J (2007) Wpływ Cynku na Występowanie i Przebieg Procesów Chorobowych u Osób Dorosłych (in Polish). Roczn. PZH 58 (3): 557-562.

[40] Schlegel-Zawadzka M (2001) Cynk: Źródła, Biodostępność, Metabolizm, Preparaty cynku. In: Nowak G, editor. Cynk w Fizjologii oraz w Patologii i Terapii Depresji (in Polish). Krakow: Instytut Farmakologii PAN. pp. 2007-2026.

[41] Wąsowicz W, Gromadzińska J, Rydzyński K, Tomczak J (2003) Selenium Status of Low - Selenium Area Residents: Polish Experience. Toxicol. lett. 137: 95-101.

[42] Zachara BA, Pawluk H, Bloch-Bogusławska E, Śliwka KM, Korenkiewicz-Skok Z, Ryć K (2001) Tissue Level, Distribution, and Total Body Selenium Content in Healthy and Diseased Humans in Poland. Arch. environ. health. 56 (5): 461-466.

[43] Holben DH, Smith AM (1999) The Diverse Role of Selenium within Selenoproteins. J. am. diet. assoc. 99 (7): 836-843.

[44] Wesołowski M, Ulewicz B (2000) Selen - Pierwiastek Śladowy Niezbędny dla Człowieka - Występowanie, Znaczenie Biologiczne i Toksyczność (in Polish). Farm. pol. 56 (21): 1004-1019. 
[45] El-Bayoumy K (1994) Evaluation of Chemopreventive Agents Breast Cancer and Proposed Strategies for Future Clinical Intervention Trials. Carcinogenesis 15: 23952420.

[46] Gromadzińska J, Reszka E, Bruzelius K, Wąsowicz W, Akesson B (2008) Selenium and Cancer: Biomarkers of Selenium Status and Molecular Action of Selenium Supplements. Eur. j. nutr. 47 (2): 29-50.

[47] Jabłońska E, Gromadzińska J, Reszka E, Wąsowicz W, Sobala W, Szeszenia-Dąbrowska N, Boffetta P (2009) Association Between GPx1 Pro198Leu Polymorphism, GPx1 Activity and Plasma Selenium Concentration in Humans. Eur. j. nutr. 48: 383-386.

[48] Reid ME, Duffield-Lillico AJ, Garland L, Turnbull BW, Clark LC, Marshall JR (2002) Selenium Supplementation and Lung Cancer Incidence: an Update of the Nutritional Prevention of Cancer Trial. Cancer epidemiol. biomarkers prev. 11: 1285-1291.

[49] Benton D (2002) Selenium Intake, Mood and Other Aspects of Psychological Functioning. Nutr. neurosci. 5 (6): 363-374.

[50] Neumeister B, Besenthal I, Liebich H (2001) Diagnostyka laboratoryjna (in Polish). Wrocław: Urban \& Partner. pp. 212-213.

[51] Socha K, Borawska MH, Gacko M, Guzowski A (2011) Diet and the Content of Selenium and Lead in Patients with Abdominal Aortic Aneurysm. VASA - European journal of vascular medicine 40 (5): 381-389.

[52] Borawska MH, Socha K, Konopka M, Mariak Z, Kochanowicz J (2010) Environmental Conditions and Selenium Status among Patients with Cerebral Aneurysms. Fresenius environ. bull. 19, 2a: 368-371.

[53] Ulewicz-Magulska B, Wesołowski M (2007) Selen jako Naturalny Składnik Mineralny Produktów Żywnościowych Pochodzenia Roślinnego (in Polish). Farm. pol. 63 (19): 869-876.

[54] Markiewicz R, Borawska MH (2005) Mięso jako Źródło Selenu w Diecie Mieszkańców Podlasia (in Polish). Bromat. chem. toksykol. 38: 249-252.

[55] Taylor D, Dalton C, Hall A, Woodroofe MN, Gardiner PH (2009) Recent Developments in Selenium Research. Br. j. biomed. sci. 66 (2): 107-116.

[56] Nabrzyski M (1998) Toksykologiczna ocena wybranych metali śladowych w żywności. In: Problemy jakości analizy śladowej $\mathrm{w}$ badaniach środowiska przyrodniczego (in Polish). Warsaw: Wydawnictwo Edukacyjne Zofii Dobkowskiej. pp. 13-40.

[57] Rogival D, Scheirs J, De Coen W, Verhagen R, Blust R (2006) Metal Blood Levels and Hematological Characteristics in Wood Mice (Apodemus Sylvaticus L.) Along a Metal Pollution Gradient. Environ. toxicol. chem. 25: 149-57.

[58] Seńczuk W (1999) Toksykologia (in Polish), Warsaw: PZWL. pp. 490-498.

[59] Zellikeff JT, Smiałowicz R, Bigazzi PE, Goyer RA (1994) Immunomodulation by Metals. Fundam. appl. toxicol. 22: 1-7.

[60] Socha K, Borawska MH, Mariak Z, Kochanowicz J, Markiewicz R, Bącławek E (2009) Dietary Habits and the Content of Lead and Cadmium in the Blood of Patients with Brain Aneurysms. Żyw. człow. metab. 36: 461-467.

[61] Brzóska MM, Jurczuk M, Moniuszko-Jakoniuk J (1997) Interakcje Kadmu z Wybranymi Biopierwiastkami (in Polish). Terapia 5: 28-30. 
[62] Merali Z, Kacew S, Sibghal RL (1975) Response of Hepatic Carbohydrate and cAMP Metabolism to Cadmium Treatment in Rats. Can. j. physiol. pharmacol. 53: 174-184.

[63] Markiewicz J (1989) Wybrane Metale Ciężkie w Środowisku Człowieka (Rtęć, Ołów, Kadm). In: Gumińska M, editor. Ekologiczne Zagrożenia Zdrowia Człowieka (in Polish). Kraków: Nauka dla wszystkich, PAN. pp. 61-78.

[64] Socha K, Borawska MH, Gacko M, Guzowski A, Markiewicz R (2005) Dieta a Zawartość Kadmu w Krwi, Subkomórkowej Ścianie i Skrzeplinie Przyściennej Tętniaka Aorty Brzusznej (in Polish). Bromat. chem. toksykol. 38: 51-55. 